\title{
Scientific Change
}

\section{Edited by A. C. CROMBIE}

Symposium on the History of Science held at the University of Oxford

The most distinguished men and women in their own fields scientists, mathematicians, sociologists, economists, philosophers and historians - gathered together from America, Europe, the U.S.S.R. and Asia, have contributed to a book which covers every aspect of scientific discovery throughout the world from the earliest times to the present day.

'Exceptional both in its range and interest ... deserves to be widely read and discussed.' The Times Educational Supplement

5 gns

\section{HEINEMANN}

15 QUEEN STREET MAYFAIR LONDON W1

\section{Three New Books}

THE ANATOMICAL LECTURES OF WILLIAM HARVEY

The Prelectiones Anatomie Universalis and De Musculis

Edited, with an introduction, translaticn and notes by

GWENETH WHITTERIDGE, M.A., D.PHIL., F.S.A.

568 pages

7 black and white plates

$£ 77$ s.

THE OTAGO MEDICAL SCHOOL INDER THE FIRST THREE DEANS

By SIR CHARLES HERCUS and SIR GORDON BELL

390 pages

37 black and white plates

$45 s$.

ST. MARY'S HOSPITALS, MANCHESTER, 1790-1963

By J. H. YOUNG, M.D., D.(Oвst.)R.C.O.G.

132 pages

31 black and white plates

$30 s$.

E. \& S. LIVINGSTONE, LTD.

TEVIOT PLACE, EDINBURGH 


\section{MICHAEL}

\section{FARADAY}

\section{A BIOGRAPHY BY \\ L. Pearce Williams}

The product of years of research and preparation, this book is a major biography of a distinguished British scientist, likely to supersede all that has gone before it and to remain the standard work on its subject for many years to come. It throws considerable fresh light on Faraday both as a man and as a scientist: and introduces and emphasises the often neglected concept of Faraday as a theorist, drawing strength for his ideas from for instance the German philosophers, as well as a brilliant experimentalist.

$70 \mathrm{~s}$
A THEATRE OF MACHINES

\section{A. G. Keller}

An anthology of plates taken from the earlest printed books of mechanical invention dating from 1570-1630, showing how an interest in machines and their potentialities arose in the society of the time.

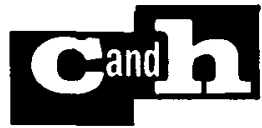

CHAPMAN \& HALL

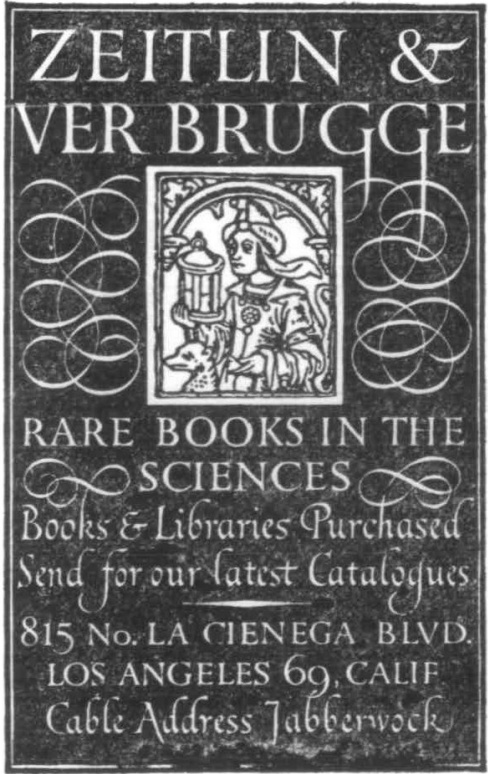




\section{THE BRITISH SOCIETY FOR THE HISTORY OF SCIENCE}

THE objects of the Society are to further the study of the history of science, by holding meetings for the reading and discussion of papers, and by facilitating the publication of relevant material.

The British Fournal for the History of Science is the official organ of the Society.

Meetings are held in the Science Museum, Exhibition Road, South Kensington, London, S.W.7, usually in January, February, March, May, June, October and November.

Membership is open to all persons approved by the Council of the Society, and elected at an Ordinary Meeting. The annual subscription is at present $£^{2}$ Ios. and includes a free issue of the Society's Journal, which appears in June and December each year.

Those who wish to join the Society should write to the Hon. Secretary, Mr. J. A. Chaldecott, Science Museum, South Kensington, London, S.W.7.

Papers for inclusion in the Journal should be submitted to the Hon. Editor, Dr. H. D. Anthony, Melrose, 102 Norcot Road, Tilehurst, Reading, Berks., from whom instructions may be obtained concerning the presentation and documentation of papers. All communications on editorial matters, and books for review, should be addressed to the Hon. Editor.

Particulars regarding advertising in the Journal may be obtained from the Hon. Treasurer, Mr. D. Chilton, Science Museum, South Kensington, London, S.W.7.

The British Fournal for the History of Science is published by the Society. Four parts constitute one Volume; each part contains approximately 96 pages. The cover of each issue has a consecutive number for ease of collation in subsequent binding, e.g. No. I6 will be numbered: Vol. Iv Part Iv No. I6, and No. I7 will be: Vol. v Part I No. I 7 .

Order Forms, with lists of contents of Parts already published, are obtainable from the Hon. Publications Secretary, Mr. F. H. C. Butler, Ravensmead, Keston, Kent, to whom Orders for the Journal should be sent.

Whole Cloth Binding Cases lettered in Gold on spine and particulars of binding costs may be obtained from Headley Brothers Ltd., InVicta Press, AshFord, Kent. 


\section{THE BRITISH JOURNAL FOR THE HISTORY OF SCIENCE}

\section{Volume in Part II December ig64 No. 6}

Martin, Thomas-Presidential Address-Early Years at the Royal Institution

Whiteside, Derek T.-Newton's Early Thoughts on Planetary Motion: A Fresh Look

Jevons, F. R.-Paracelsus's Two-way Astrology

I. What Paracelsus meant by 'Stars'

II. Man's Relation to the Stars

Jefrreys, Alan-Locating the Manuscript Sources of Science

Report of the Ninth Colloquium on the History of Mathematics

I 57-I6I

Essay Review

$162-164$

Book Reviews

$165-168$

Books Received

I69-1 7 I

Correspondence Concerning Galileo

I $72-173$

Obituary

Papers in Current Periodicals

Items of Interest from other Publications

Notes on Contributors

Report of Council and Financial Statement

PUBLISHED BY THE BRITISH SOCIETY FOR THE HISTORY OF SGIENCE

Registered Office: Science Museum, South Kensington, London, S.W.7

Brit. J. Hist. Sci. 2 no 6 . Price 15 Shillings. Free to Members of the Society. Published December 1964 